\title{
Co-infection by porcine circovirus type 2 and porcine parvovirus in aborted fetuses and stillborn piglets in southern Brazil ${ }^{1}$
}

\author{
Caroline A. Pescador ${ }^{2}$, Paulo M. Bandarra ${ }^{2}$, Luiza A. Castro ${ }^{3}$, Nadia A.B. Antoniassi ${ }^{4}$, \\ Ana Paula Ravazzolo ${ }^{2}$, Luciana Sonne ${ }^{2}$, Cláudio E.F. Cruz ${ }^{2}$ e David Driemeier ${ }^{2}$
}

\begin{abstract}
Pescador C.A., Bandarra P.M., Castro L.A., Antoniassi N.A.B., Ravazollo, A.P., Sonne L. Cruz C.E.F. \& Driemeier D. 2007. Co-infection by porcine circovirus type 2 and porcine parvovirus in aborted fetuses and stillborn piglets in southern Brazil. Pesquisa Veterinária Brasileira 27(10):425-429. Departamento de Patologia Clínica Veterinária, Universidade Federal do Rio Grande do Sul, Av. Bento Gonçalves 9090, Porto Alegre, RS 91540-000, Brazil. E-mail: davetpat@ufrgs.br

Porcine circovirus types 1 and 2 (PCV1, PCV2) and porcine parvovirus (PPV) are widespread in pig populations around the world. Nevertheless, only PCV2 has been associated with different clinical syndromes, thus representing a major problem to the pig industry. The association of cases of swine abortions and stillborns with PCV1 and PCV2 and PPV was studied retrospectively (2005-2007). Additional pathogens were also investigated in lesioned fetuses. The studied litters included stillborn piglets and several mummified fetuses of varied sizes. Ventricular dilatation, myocardial pale areas, and mesocolic edema were the gross lesions. Escherichia coli was detected as co-infecting with PCV2 the cases in which mesocolic edema was seen. Microscopic lesions included non-suppurative myocarditis, myocardial necrosis and fibrosis, mineralization foci and intranuclear inclusion bodies in cardiomyocytes, and interstitial mononuclear pneumonia. Samples from 7 (5.78 per cent) of 121 aborted fetuses and stillborn piglets had lesions consistent with a viral cause and showed both positive anti-PCV2 immunostaining as well as PCV2-PCR. In samples from 3 (2.47 per cent) of these 7 fetuses, coinfection with PPV was confirmed by Nested-PCR. Both viruses were detected in fetuses at different stages of gestation. Viral antigens of PCV2 were detected by immunohistochemistry mainly in macrophages and myocytes. PCV1 individually was not detected in any of these affected fetuses, but it was associated with PCV2 and/or PPV in some of them. These findings indicate that PCV2 alone or in association with PPV should be kept in mind when investigating causes of infectious abortion in pigs in Brazil.
\end{abstract}

INDEX TERMS: Abortion, PCV2, PCV1, PPV, stillborn, swine, Brazil.

RESUMO.- [Co-infecção por circovírus suíno tipo 2 e parvovírus suíno em fetos abortados e natimortos suínos no Sul do Brasil.] Estudou-se retrospectivamente (2005-2007) a associação de casos de abortos e natimortos suínos com infec-

\footnotetext{
${ }^{1}$ Received on June 29, 2007.

Accepted for publication on September 6, 2007

2 Deptartamento de Patologia Clínica Veterinária, Universidade Federal do Rio Grande do Sul (UFRGS), Av. Bento Gonçalves 9090, Porto Alegre, RS 91540-000, Brazil. "Corresponding author: davetpat@ufrgs.br

${ }^{3}$ Centro de Biotecnologia, UFRGS, Pós-Doutorado Júnior (PDJ) do CNPq (Proc.155528/2006-8).

${ }^{4}$ Graduanda do Curso de Medicina Veterinária, Universidade Federal de Mato Grosso (UFMT), Coxipó, 78060-900 Cuiabá, MT, Brazil.
}

ções por circovírus suíno (PCV) tipos 1 e 2 e parvovírus suíno (PPV). Outros agentes patogênicos foram pesquisados em amostras de fetos com lesões. $\mathrm{O}$ estudo incluiu natimortos e fetos mumificados de tamanhos variados. Dilatação ventricular, áreas pálidas miocárdicas e edema de mesocólon foram as lesões macroscópicas observadas. Escherichia coli coinfectou com PCV2 as amostras dos casos com edema de mesocólon. Lesões microscópicas incluíram miocardite não supurativa, necrose e fibrose miocárdicas, focos de mineralização e corpúsculos de inclusão em cardiomiócitos e pneumonia intersticial mononuclear. Entre os 121 fetos suínos abortados ou natimortos analisados, sete $(5,78 \%)$ tinham lesões compatíveis com origem viral e foram positivos pelas técnicas de imunoistoquímica e PCR para PCV2. Além disso, 
três $(2.47 \%)$ desses sete casos também foram confirmados como co-infectados com PPV através da PCR. Antígenos de PCV2 foram observados principalmente em macrógafos e no interior de miócitos dos fetos suínos abortados e natimortos. PCV2 e PPV foram detectados em diferentes estágios de gestação. PCV1 não foi associado isoladamente com feto ou natimorto afetado, mas estava presente em associação com PCV2 e/ou PPV em alguns desses produtos. Esses achados indicam que a infecção por PCV2, isoladamente ou em associação com PPV, deve ser considerada no diagnóstico de aborto infeccioso suíno no Brasil.

TERMOS DE INDEXAÇÃO: Aborto, natimorto, PCV1, PCV2, PPV, suíno, Brasil.

\section{INTRODUCTION}

Porcine circovirus 2 (PCV2) is widespread in pig populations in many parts of the world (Allan \& Ellis 2000). Since its association with porcine postweaning multisystemic wasting syndrome (PMWS) (Ellis et al. 1998), PCV2 has been linked with many other clinical syndromes in pigs (West et al. 1999, Ellis et al. 2000, Rosell et al. 2000).

Pigs with PMWS are often infected with a variety of other pathogens, including bacteria, viruses, and protozoa, in addition to PCV2. The co-infection by PCV2 and porcine parvovirus (PPV) has been associated with naturally (Ellis et al. 2000) and experimentally PMWS affected pigs (Kennedy et al. 2000, Krakowka et al. 2000), but only sporadically with swine abortion (Altherr et al. 2003). Although PPV is thought to be endemic in pig populations throughout the world (Mengeling 1992), it has only rarely been associated with any disease in pigs other than fetal death (Kresse et al. 1985, Bolt et al. 1997). Most available data indicate that the apparently universal exposure to PPV in pigs was almost exclusively associated with sub-clinical infection and development of immunity (Mengeling 1992). In Brazil, the experimental coinfection PCV2 and PPV was described in SPF (Specific Pathogen Free) pigs (Fernandes et al. 2006). However, in this country, there is limited information concerning infectious causes of swine abortion (Oliveira et al. 1997, Castro et al. 2004).

In addition, although PCV1 was initially considered as a nonpathogenic virus (Allan et al. 1995), it has been detected in pigs affected by wasting disease (LeCann et al. 1997, Ellis et al. 2000). The objectives of this study were to determine the prevalence of PCV1, PCV2, and PPV infections in aborted fetuses and stillborn piglets in Southern Brazil, and to determine the distribution of the PCV2 in their tissues by immunohistochemistry.

\section{MATERIALS AND METHODS}

This study comprised 121 aborted fetuses or stillborn piglets, which were submitted from nine pig farms between July 2005 and March 2007 for diagnostic purposes. At necropsy, samples of brain, heart, lung, liver, kidney, skeletal muscle, lymph nodes, thymus, spiral colon and spleen were collected from all cases. Subsequently, these samples were fixed in $10 \%$ buffered formalin, processed by routine methods, sectioned at $4 \mu \mathrm{m}$, mounted and stained with hematoxylin and eosin
(HE), and microscopically evaluated. Samples of the lungs, liver and stomach contents of each case with microscopic lesions were cultured for aerobic bacteria.

Samples from all cases were also screened for the presence of PCV2 and porcine parvovirus (PPV) by immunohistochemistry and nested polymerase chain reaction (PCR), respectively. Detection of spirochetes in kidney smears through the use of multivalent antibody conjugated with fluorescein (NVLS) at 1:20 dilution was employed for the diagnosis of Leptospira spp. infection (Miller et al. 1989) in samples from cases with microscopic lesions. Finally, PCR for detection of PCV1 and PCV2 and immunostaining (IS) procedure against PRRSV were conducted in samples from cases in which microscopic lesions were present.

In the anti-PCV2 IS, the sections were dewaxed in xylene and rehydrated through graded alcohols. Endogenous peroxidase activity was quenched by treating sections with $\mathrm{H}_{2} \mathrm{O}_{2}$ for 20 minutes. After rinsing in distilled water, the sections were digested with Protease XIV (Sigma Chemical Company, Poole, UK) at a concentration of $0.5 \mathrm{mg} / \mathrm{ml}$ in TBS for 15 minutes at 37C. After rinsing in distilled water, they were incubated in $5 \%$ milk solution (Molico ${ }^{\circledR}$ ) for 20 minutes at room temperature to prevent background labeling. The sections were then incubated in a solution of rabbit anti-PCV2 antiserum, diluted in 1:1000 in TBS, for 1 hour at 37C. After washing in TBS, an avidin-biotin-peroxidase complex (ABC) kit (Dako, Carpinteria, CA) was employed for $15 \mathrm{~min}$ as the IHC detection system. The sections were then washed in TBS for 5 minutes and the reaction "visualized" by applying 3,3"diaminobenzidine (DAB; Dako, Carpinteria, CA) for 10 to 15 minutes. Finally, the sections were lightly counterstained with Mayer's haematoxylin for light microscopic examination. Positive controls were included in each immunohistochemical procedure.

Total DNA extracted using the Ultraclean Tissue DNA Isolation Kit (Mobio Laboratories, Inc) from 30mg of aborted fetus lung was used as template in nested-PCR analysis. The PCR primers for PCV1 and PCV2 were described by Kim et al. (2003), and the PPV primers were the same of those used by Soares et al. (1999). The amplifications were performed in a $50 \mathrm{ml}$ reaction mixture containing $3 \mathrm{mM} \mathrm{MgCl} 2$ for PPV and $1 \mathrm{mM}$ for PCV, $1 \mathrm{x}$ PCR buffer, $0.2 \mathrm{mM}$ of each dNTP, 20pmol of each primer, and 2.5U of Taq DNA polymerase (Cenbiot enzimas), at $55^{\circ} \mathrm{C}$ (PCV1 and PPV) and $60^{\circ} \mathrm{C}$ PCV2 (Soares et al. 1999, Kim et al. 2003). The PCR reactions were performed in triplicate in an automated DNA thermal cycler (Eppendorf Mastercycler ${ }^{\circledR}$ personal, Westbury, NY). Control DNA from the reference strain for PPV, PCV1 and PCV2 were included in each reaction. PCR products were resolved on a $1.5 \%$ agarose gel in TBE buffer and visualized by ethidium bromide staining.

\section{RESULTS}

Of the 121 swine fetuses or stillborn, 7 (5.78\%) had lesions characterized by mononuclear inflammation consistent with a viral infection. Of these, 2 cases were positive for PCV2 alone, 2 cases were positive for PCV1 and PCV2 together, and the other 3 cases were positive for both PCV2 and PPV. The litters that were received for postmortem examination included stillborn piglets and several mummified fetuses with sizes varying from 6-26 cm crown-rump length (Fig.1) There was excessive fluid in the thoracic cavities from all the 7 cases, of which, 4 also had lesions characteristic of heart failure, i.e. marked ventricular dilatation and pale areas in the myocardium (Fig.2) Mesocolic edema (Fig.3) was seen in two cases, from which pure cultures of Escherichia coli grew (aerobic culture) in samples of lung, liver and stomach contents. Gross 


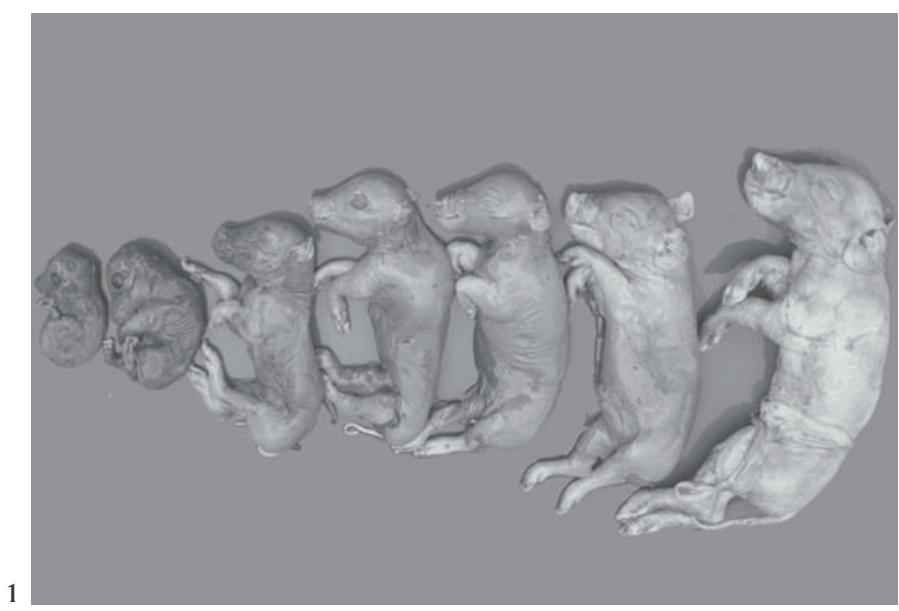

Fig.1. Litter with dead and mummified fetuses with sizes varying from 6 to $26 \mathrm{~cm}$ crown-rump length.

Fig.2. Transverse section of the ventricular myocardium from a stillborn piglet infected with PCV2. Note marked ventricular dilatation and pale areas.

Fig.3. Serosal surface of spiral colon tissue from a stillborn piglet naturally infected with PCV2. Note moderate generalized edema in the spiral colon.

findings and results of bacteriologic tests are shown in Table 1. The direct immunofluorescence test for Leptospira sp. was negative in all 7 cases.

Histologically, there was severe, non-suppurative myocarditis (Fig.4) and, often, myocardial necrosis with moderate fibrosis. There also were foci of mineralization and intranuclear inclusion bodies in cardiomyocytes and pulmonary multifocal mononuclear cell infiltrate. No significant histopathological changes were observed in the other organs. Immunohistochemical staining (Table 2) revealed large amounts of PCV2 antigens in the cytoplasm and nuclei of a wide range of lymphoid and non-lymphoid tissues, but mostly in myocardial lesions (Fig.5) from the 7 cases. The antigen was mainly observed throughout the inflammatory cells and into the myocytes.

PCV2 antigen was located in mononuclear cells and syncytia in lymphoid follicles in spleen. In thymus, PCV2 was widely distributed in histiocytic cells. Intense cytoplasmic and

Table 1. Summary of gross lesions in swine fetuses infected naturally with porcine circovirus 1 and 2 (PCV1 and 2) in conjunction or not with porcine parvovirus (PPV)

\begin{tabular}{|c|c|c|c|c|}
\hline Cases & Age (days) & Infection & Gross lesions & Bacterial growth \\
\hline 1 & 117 & PCV2 & $\begin{array}{l}\text { Pale areas in the } \\
\text { myocardium }\end{array}$ & None \\
\hline 2 & 119 & PCV1 + PCV2 & Mesocolic edema & Escherichia coli \\
\hline 3 & $\mathrm{ND}^{\mathrm{a}}$ & PCV1 + PCV2 & Mesocolic edema & Escherichia coli \\
\hline 4 & 118 & PCV2 & Ventricular dilatation & None \\
\hline 5 & 118 & PCV1 + PCV2 + PPV & Ventricular dilatation & None \\
\hline 6 & ND & PCV1 + PCV2 + PPV & Ventricular dilatation & None \\
\hline 7 & 115 & PCV1 + PCV2 + PPV & Absent & None \\
\hline
\end{tabular}

${ }^{\mathrm{a}} \mathrm{ND}=$ not determined.
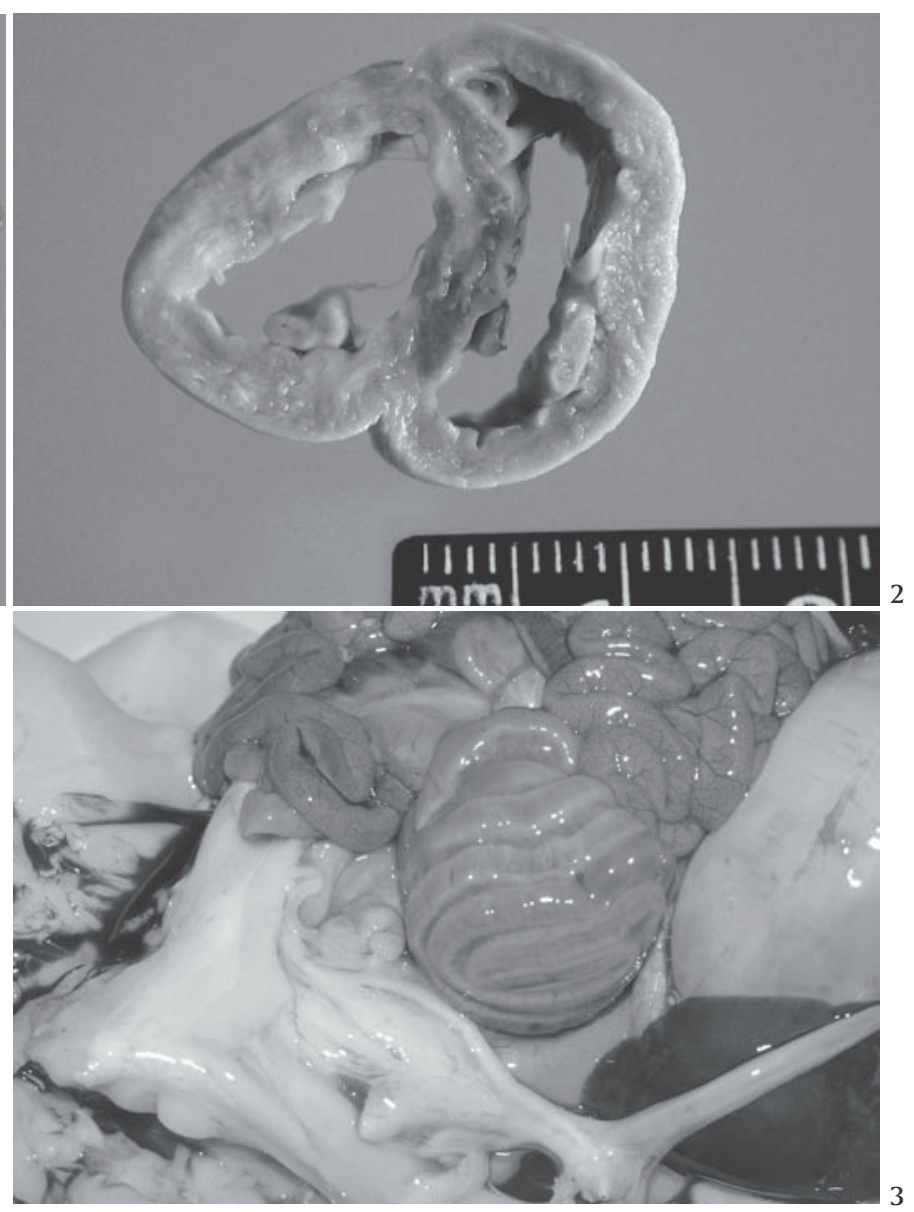

nuclear labelling was seen in thymic syncytia and in cells suggestive of lymphocytes. In lymph nodes, prominent accumulations of viral antigen were detected chiefly in macrophages and follicular cells. Large solid deposits of antigen were frequently aparent in nuclei. Antigen was mainly confined to follicular region of the cortex and paracortex, but in macrophages and syncytia in the medullary and subcapsular sinusoids. In the lungs, PCV2 was demonstrated

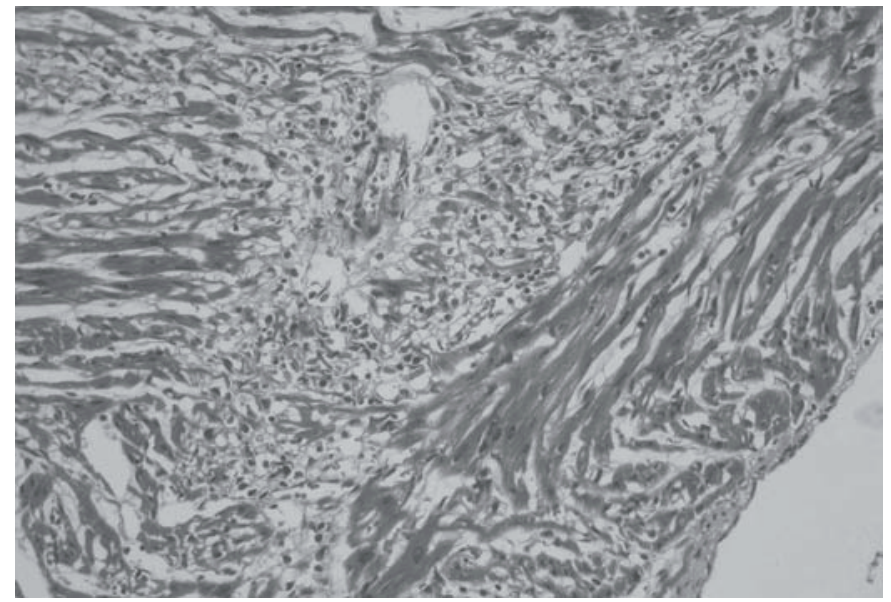

Fig.4. Heart from a fetus with marked diffuse non-suppurative myocarditis. HE, obj.20x. 


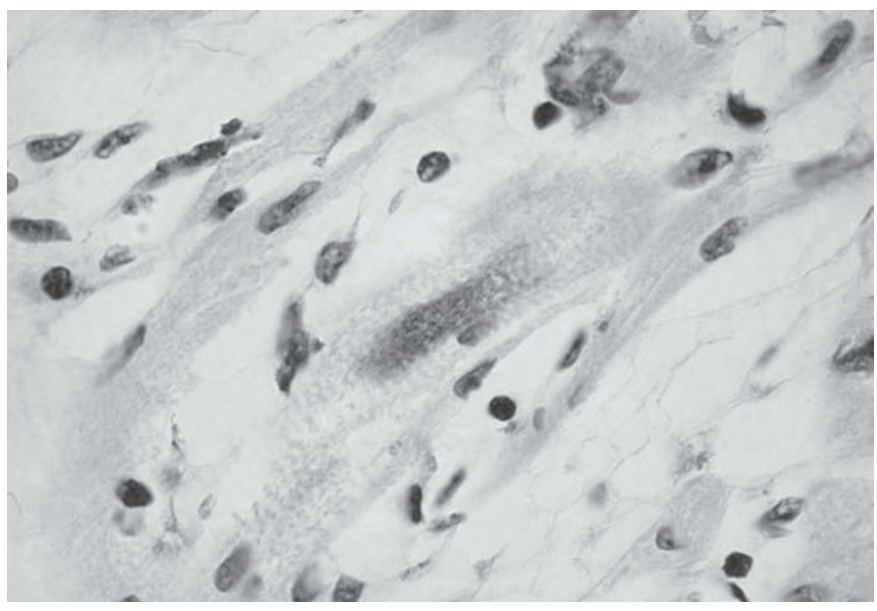

Fig.5. Myocardial tissue from an aborted fetus. Myocytes containing PCV2 antigen. Streptavidin-biotin-immunoperoxidase technique counterstained with haematoxylin. Obj.100x.

Table 2. Immunohistochemical (IHC) results for porcine circovirus type 2 in tissues of aborted fetuses and stillborn piglets naturally infected with PCV2

\begin{tabular}{cccccccccc}
\hline \multirow{2}{*}{ Cases } & \multicolumn{7}{c}{ Tissues $^{\mathrm{a}}$} \\
\cline { 2 - 8 } & Lung & Liver & Kidney Lymph nodes & Spleen & Thymus & Colon & Heart \\
\hline 1 & + & + & + & +++ & + & +++ & ++ & +++ \\
2 & ++ & ++ & ++ & - & ++ & ++ & + & +++ \\
3 & ++ & + & + & +++ & ++ & - & +++ & +++ \\
4 & - & + & - & ++ & + & + & - & +++ \\
5 & - & - & - & ++ & ++ & - & + & +++ \\
6 & - & - & - & + & - & - & ++ & +++ \\
7 & - & - & - & ++ & ++ & - & & +++ \\
\hline
\end{tabular}

a Distribution pattern of PCV2 antigen throughout tissues: negative (-), mild $(+)$, moderate $(++)$, and intense $(+++)$ labelling.

in alveolar septal and alveolar epithelial cells. In three fetuses there was a mild staining in the liver, predominantly in sinusoidal endothelium and hepatocytes. Positively stained cells were scattered multifocally in the kidney. Additionally, viral antigen was seen in follicular centers in the spiral colon.

Porcine parvovirus (PPV) was demonstrated in the lungs of stillborn fetuses from two cases in combination with PCV2 (Table 2). Immunohistochemical test for PRRSV was negative in all 7 cases.

\section{DISCUSSION}

Many reports have reported a world-wide distribution of PCV2 in swine population, causing important economic losses to the swine industry (Macdonald et al. 2003, Kim et al. 2004, Chae 2004). Moreover, PCV2 has been linked to swine abortion, stillborn, fetal mummification and birth of weak piglets (West et al. 1999, Bogdan et al. 2001, O'Conner et al. 2001, Pensaert et al. 2004). However, as has already been suggested (Alterr et al. 2003) the low number of PCV2 infected fetuses probably reflects a minor role for the vertical transmission in the PCV2 pathogenesis.

Myocarditis, pale myocardial areas, ventricular dilatation, hydrothorax, ascites, liver enlargement, and abortion have all been associated with PCV2 intrauterine infection of sows
(West et al. 1999, Brunborg et al. in publication). In the present study, these cardiac lesions were also associated with PCV2 infection, but they were most prominent in aborted piglets in which PCV2 and PPV co-infection was detected, indicating again that the disease caused by the PCV2/PPV co-infection may be more severe than that caused by PCV2 alone. This synergistic action of PCV2 and PPV in aborted swine fetuses had also been demonstrated in Germany (Alterr et al. 2003).

Co-infection by PCV2 and PPV have been associated with naturally (Ellis et al. 2000) and experimentally (Kennedy et al. 2000, Krakowka et al. 2000) PMWS affected pigs and aborted swine fetuses (Altherr et al. 2003). Porcine parvovirus replicates in cells of the monocyte-macrophage series and may produce immune cell dysfunction, activation or immunosuppression causing an enhanced replication of PCV2 in affeted pigs. Alternatively, PCV2 may initiate lymphoid depletion, resulting in an increased susceptibility to other viral or bacterial infections (Harding \& Molitor 1988, Kennedy et al. 2000). This co-infection could be expected, since both viruses are worldwide distributed (Mengeling 1992, Allan \& Ellis 2000).

Mesocolic edema is a characteristic lesion caused by Escherichia coli infection in pigs. This lesion was found in two aborted fetuses co-infected naturally with PCV2 and Escherichia coli, which was isolated in pure culture from samples of liver, lung and stomach fluid. However, a direct PCV2-induced vascular damage (Kennedy et al. 2000) may also has contributed to or caused those lesions. Mesocolic edema in swine aborted fetuses may also result from PRRSV infection (Rossow 1998), but it was not detected here by immunohistochemistry. Furthermore, a recent report indicated that PRRSV infection was not found in Brazil yet (Zanella et al. 2004).

Histological lesions associated with PCV2 were mainly observed in the heart and were characterized by nonsuppurative inflammation and varying degrees of fibrosis and necrosis, indicating possible variation in the duration of lesion development. PCV2 antigens have been detected in several swine tissues by monoclonal and polyclonal antibody-based immunohistochemical procedures (Ellis et al. 1998, Choi \& Chae 2000). As previously seen (Kim et al. 2004, Sanchez et al. 2004), the hearts and lymph nodes were consistently positive in all stillborns piglets and thus they may serve as target organs for diagnosing fetal infection.

Since PCV1 alone was not detected in any affected swine fetus, this report also strenghtened the hypothesis of its lack of pathogenicity (Allan et al. 1995). The results of this study warrant the inclusion of PCV2 and PPV in the list of differential diagnoses for cases of swine reproductive losses in Brazil.

Acknowledgements.- The research was supported by CAPES, Brazil. The senior author thanks Ms. Francesca McClure Smith for her assistance with English.

\section{REFERENCES}

Allan G.M., McNeilly F., Cassidy J.P., Reilly G.A., Adair B., Ellis W.A. \& McNulty M.S. 1995. Pathogenesis of porcine circovirus; experimental infections of colostrum deprived piglets and examination of pig fetal material. Vet. Microbiol. 44:49-64. 
Allan G.M. \& Ellis J.A. 2000. Porcine circovirus: a review. J. Vet. Diagn. Invest. 12:3-14.

Altherr B., Zimmermann P., Etschmann B., Ritzmann M., Heinritzi M., Selbitz H.J. \& Truyen U. 2003. Detection of porcine circovirus type 2 (PCV2) and porcine parvovirus (PPV) in aborted fetuses. 4th International Symposium on Emerging and Re-emerging Pig Disease, Rome, p.218-219.

Bogdan J., West K., Clark E., Konoby C., Haines D., Allen G., McNeily F., Meehan B., Krakowka S. \& Ellis J.A. 2001. Association of porcine circovirus 2 with reproductive failure in pigs: a retrospective study, 1995-1998. Can. Vet. J. 4:548-550.

Bolt D.M., Hani H., Muller E. \& Waldvogel A.S. 1997. Nonsuppurative myocarditis in piglets associated with porcine parvovirus infection. J. Comp. Pathol. 117:107-118.

Brunborg I.M., Jonassen C.M., Moldal T., Bratberg B., Lium B., Koenen F., Schönheit J. Association of myocarditis with high viral load of porcine circovirus type 2 in several tissues in cases of fetal death and high mortality in piglets: a case study. J. Vet. Diagn. Invest. (In publication)

Castro A.M.M.G., Cortez A., Ruiz V.L.A., Leomil H., Moreno A.M., Doto D.S. \& Richtzenhain L.J. 2004. Detection and differentiation of porcine circoviruses in Brazilian pigs. Vet. Rec. 154:728-729.

Chae C. 2004. Postwening multisystemic wasting syndrome: a review of aetiology, diagnosis and pathology. Vet. J. 168:41-49.

Choi C. \& Chae C. 2000. Distribution of porcine parvovirus in porcine circovirus 2-infected pigs with postweaning multisystemic wasting syndrome as show by in-situ hybridization. J. Comp. Pathol. 38:436441.

Ellis J., Hassard L., Clark E., Harding J., Allan G., Willson P., Strokappe J., Martin K., McNeilly F., Meehan B., Todd D. \& Haines D. 1998. Isolation of circovirus from lesions of pigs with postweaning multisystemic wasting syndrome. Can. Vet. J. 39:44-51.

Ellis J.A., Bratanich A., Clark E.G., Allan G., Meehan B., Haines D.M., Harding J., West K.H., Krakowka S., Konoby C., Hassard L., Martin K. \& McNeilly F. 2000. Co-infection by porcine circoviruses and porcine parvovirus in pigs with naturally acquired postweaning multisystemic wasting syndrome. J. Vet. Diagn. Invest. 12:21-27.

Fernandes L.T., Ciacci-Zanella J.R., Sobestiansky J., Schiochet M.F. \& Trombetta C. 2006. Experimental coinfection of SPF pigs with porcine circovirus type 2 isolated in Brazil and porcine parvovirus. Arq. Bras. Med. Vet. Zootec. 58:1-8.

Harding M.J. \& Molitor T.W. 1988. Porcine parvovirus: replication in and inhibition of selected cellular functions of swine alveolar macrophages and peripheral blood lukocytes. Arch. Virol. 101:105-117.

Kennedy S., Moffett D., McNeilly F., Meehan B., Ellis J., Krakowka S. \& Allan G.M. 2000. Reproduction of lesions of postweaning multisystemic wasting syndrome by infection of conventional pigs with porcine circovirus type 2 alone or in combination with porcine parvovirus. J. Comp. Pathol. 122:924.

Kim J. \& Chae C. 2003. Multiplex nested PCR compared with in situ hybridization for the differentiation of porcine circoviruses and porcine parvovirus from pigs with postweaning multisystemic wasting syndrome. Can. J. Vet. Res. 67:133-137.
Kim J., Jung K. \& Chae C. 2004. Prevalence of porcine circovirus type 2 in aborted fetuses and stillborn piglets. Vet. Rec. 16:489-492.

Krakowka S., Ellis J.A., Meehan B., Kennedy S., McNeilly F. \& Allan G. 2000. Viral wasting syndrome of swine: experimental reproduction of postweaning multisystemic wasting syndrome in gnotobiotic swine by coinfection with porcine circovirus e and porcine parvovirus. Vet. Pathol. 37:254-263.

Kresse J.F., Taylor W.D., Stewart W.W. \& Eernisse K.A. 1985. Parvovirus infection in pigs with necrotic and vesicle-like lesion. Vet. Microbiol. 10:525-531.

LeCann P., Albina E., Madec F., Cariolet R. \& Jestin A. 1997. Piglet wasting disease. Vet Rec. 141:660.

MacDonald W.F., Choi Y.K., Goyal S.M. \& Joo H.S. 2003. Isolation and characterization of porcine circovirus type 2 from sera of stillborn fetuses. Can. J. Vet. Res. 67:108-113.

Mengeling W.L. 1992. Porcine parvovirus infection, p.299-311. In: Leman A.D., Straw B., Meningeling W.L., D'Allaire S. \& Taylor D.D. (ed.), Disease of Swine. $7^{\text {th }}$ ed. Iowa State University, Ames,

Miller D.A., Wilson M.A. \& Kirkbride C.A. 1989. Evaluation of multivalent Leptospira fluorescent antibody conjugates of general diagnostic use. J. Vet. Diagn. Invest. 1:146-149.

O'Conner B., Gauvreau H., West K., Bogdan J., Ayroud M., Clark E.G., Konoby C., Allen G. \& Ellis J.A. 2001. Multiple porcine circovirus 2- associated abortions and reproductive failure in a multiside swine production unit. Can. Vet. J. 42:551-553.

Oliveira S.J., Baetz A.L., Wesley I.V. \& Harmon K.M. 1997. Classification of Arcobacter species isolated from aborted pig fetuses and sows with reproductive problems in Brazil. Vet. Microbiol. 57:347-354.

Pensaert M.B., Sanchez R.E., Ladekjaer-Mikkelsen A.S., Allan G.M. \& Nauwynck H.J. 2004. Viremia and effect of fetal infection with porcine viruses with special reference to porcine circovirus 2 infection. Vet. Microbiol. 98:175-183.

Rosell C., Segales J., Ramos-Vara J.A, Folch J.M., Rodríguez-Arrioja G.M., Duran C.O., Balasch M., Plana-Durán J. \& Domingo M. 2000. Identification of porcine circovirus in tissue of pigs with porcine dermatitis and nephropathy syndrome. Vet. Rec. 146:40-43.

Rossow K.D. 1998. Review article: porcine reproductive and respiratory syndrome. Vet. Pathol. 35:1-20.

Sanchez Jr. R.E, Nauwynck H.J., McNeilly F., Allan G.M. \& Pensaert M.B. 2001. Porcine Circovirus 2 infection in wine fetuses inoculated at diferent stages of gestation. Vet. Microbiol. 83:169-176.

Soares R.M., Durignon E.L., Bersano J.G. \& Richtzenhain L.J. 1999. Detection of porcine parvovirus DNA by polymerase chain reaction assay using primers to the highly conserved nonstructural protein gene, NS-1. J. Virol. Methods 78:191-198.

West H., Bystrom J.M., Wojnarowicz C., Shantz N., Jacobson M., Allan G.M., Haines D.B., Clark E.G., Krakowka S., McNeilly F.M., Konoby C., Martin K. \& Ellis J.A. 1999. Myocarditis and abortion associated with intra-uterine infection of sows with porcine circovirus 2. J. Vet. Diag. Invest. 11:530-532.

Zanella J.R.C., Trombetta C., Vargas I. \& Costa D.E.M. 2004. Lack of evidence of porcine reproductive and respiratory syndrome virus. Ciência Rural, Santa Maria, 34:449-455. 